\title{
The influence of internal audit and internal control on fraud prevention in Bandung regency government
}

\author{
Ony Widilestariningtyas ${ }^{1,}{ }^{*}$, Rio Sempana Karo Karo ${ }^{2}$ \\ 1,2 Universitas Komputer, Indonesia
}

\section{Keywords:}

Internal audit

Internal control

Fraud prevention

Received: 21 October 2015

Accepted: 10 January 2016

Published: 21 June 2016

\begin{abstract}
This research is conducted in Bandung regency government. The phenomenon that occurs is the case of internal control weaknesses, such as accounting and reporting control weaknesses, as well as cases of weakness of internal control structure. The existence of such fraud is non-compliant with the regulations resulting in a loss of area and the surrender value of assets or deposit cash into countries/regions. The research objectives are to determine how big the influence of internal audit is on fraud prevention and internal control on fraud prevention in District of Bandung Government. The methods used in this research are descriptive and verification method. Descriptive method is used to determine the variable picture of internal audit, internal control variables and variables of fraud prevention. To determine the effect of internal audit and internal control statistical tests were performed. The test statistic used is designing the structural model, designing a measurement model, construct the path diagram and test the model fit. Suitability test structural models and hypotheses were tested using software SmartPLS 2.0.M3.The result of this research reveals the coefficient of correlation between internal audit on fraud prevention is 0.422 . The internal audit influence on fraud prevention in District of Bandung Government in percentage is $8.566 \%$. The rest of it with a value of $91.434 \%$ is influenced by other factors unobserved in this research. The correlation coefficient between internal control on fraud prevention in District of Bandung Government is about $27.878 \%$. The rest of it with a value of $72.122 \%$ is influenced by other factors unobserved in this research.
\end{abstract}

(C) 2016 The Author(s). Published by TAF Publishing.

\section{INTRODUCTION}

The occurring fraud cases in Indonesia recently have attracted the government attention and the community (Nisak \& Kurniawan, 2013). According to Fitrawansyah, the fraud prevention is an activity to counter fraud with low cost because fraud prevention can be associated with disease which is better to prevent than to cure (Festi \&

\footnotetext{
*Corresponding author: Ony Widilestariningtyas
}

E-mail: onykulestari@yahoo.com
Natariasari, 2014). There are three kinds of frauds; first, the misuse and fraud of assets involving active entity theft; second, false statement on financial report or value neglection or deliberate statement with an intention to trick the financial report recipients; third, corruption and misuse of position in government sector for personal purposes (Tuanakotta, 2010). In Bandung Regency Government, there are 34 reported cases, with 14 internal control weakness cases, 16 defiance cases of rules and 
regulations resulting in regional losses, and 4 cases of assets value giving or regional/governmental cash deposit on findings which are in a process of investigation (Aziz, 2014). Internal audit plays an important role in observing and monitoring the activities and assures that anti-fraud control program is running effectively and internal audit activities could prevent as well as detect frauds (Amalia, 2013). With the presence of internal audit, frauds and errors and other disadvantaging efforts in an organization can be reduced and even prevented (Gusnardi, 2011). Internal audit in government agencies isn't running its jobs optimally (Didi, 2008). Islahudin contends that fraud cases occuring in Indonesian government are caused by the termination of internal audit and detection system, such as ineffective regional monitoring institution because it is staffed by misfits and staff who is about to retire (Robert, 2013). Internal Control System (ICS) in implementation must always consider norms of justice and obedience as well as considering size of complexity and nature of its duties and government agencies' functions (Mulyani \& Suryawati 2013). In Bandung Regency Government, there are 14 reported cases of ICS with 9 accounting reporting and control weaknesses, 2 system weaknesses on income and expense cost control, and 3 internal control structure weaknesses (Aziz, 2014). ICS is a policy and procedure designed to provide significant trust to management as a proof of the fact that organization has accomplished its goal and targets (Agung, 2010).

\section{Problem Identification}

1. How significantly does the internal audit affect the fraud prevention in Bandung Regency Government?

2. How significant is the influence of internal control with respect to fraud prevention in Bandung Regency Government?

\section{Research Purposes}

The purpose of this research is to collect information on internal audit, internal control system, fraud prevention, empirical proof of internal audit, and internal control system that affects the fraud prevention in Bandung Regency Government. The purposes of this research are:

1. To acknowledge how significantly the internal audit affects the fraud prevention in Bandung Regency Government.

2. To know how significant the internal control is with respect to fraud prevention in Bandung Regency Government.

\section{RESEARCH USABILITY}

Practical Usability

The result of this research is meant to find solutions of problems within internal audit, internal control, and fraud prevention in Bandung Regency Government. The practical usability of this research is as follows:

\section{For Inspectorates}

As a medium of consideration, it is useful for inspectorates in order to find significant effects from internal audit and internal control system with respect to fraud prevention in Bandung Regency Government so they could do improvements.

\section{For Internal Auditors}

As information and inputs in doing their jobs and maximizing its functionalities so fraud prevention in Bandung Regency Government is effective.

\section{Academic Usability}

\section{For Public Sector Accounting Developers}

Could add knowledge and provide scientific research particularly to public sector accounting on the effect of internal audit and internal control with respect to fraud prevention by proving theoretically and through prior researches.

\section{Writer}

To increase or comprehend the knowledge and understandings, to find solutions found by writeron internal audit and intern control on fraud prevention. This research is also useful as a final project reference in order to obtain undergraduate degree at Faculty of Economy at Universitas Komputer Indonesia (UNIKOM), Bandung.

\section{Other Researchers}

This research is expected to provide deep knowledge and information or reference required by other researchers for further development in internal audit and internal control on fraud prevention.

\section{LITERATURE REVIEW}

\section{Internal Audit}

According to Sukrisno (cited by Hery, 2010:57) it is defined thatinternal audit is a checking done by entity of internal audit of financial reports and accounting notes entity and also for obedience of top level management 
regulations, obedience of government issues and regulations related to profession. The government rules like tax, environment, banking, industries, investment, etc. According to Tugiman (2006:53) internal check process should have four stages:

1. Checking planning

2. Information evaluation and test

3. Checking result publication

4. Checking follow up

\section{Internal Control}

According to Rahayu \& Suhayati (2010:221), internal control explains about the internal control within a process, influenced by board of commissioners, management, and other personnel within an entity, designed to provide trust in order to accomplish goals, such as rigid financial report, maintaining assets and organizational notes, obedience of rules and regulations, and operation effectivity and efficiency. According to Rahayu \& Suhayati (2010:223) an internal control must consist of 5 components:

1. Environment Control

2. Risk Management Implementation

3. Activities Control

4. Accounting Information and Communication

5. Observation

\section{Fraud Prevention}

According to Amrizal (2004:5), fraud prevention is activity done by management to implement policies, system, and supporting procedures to ensure that required activities have been done by board of commissioners, management, and other personnel in a company to provide trust in accomplishing three goals; rigid financial report, effective and efficient operations, and obedience to rules and regulations. According to Amrizal (2004:5) fraud detection that might occur should be prevented by these following ways:

1. Establish a good internal control structure

2. To make effective use of activity control

3. Organizational culture improvement

4. To make effective use of internal audit function

\section{Knowledge Framework}

\section{Internal Audit Effect on Fraud Prevention}

According to survey by Widilestariningtyas (2012) the relation between internal audit and fraud prevention is that internal audit affects significantly on fraud prevention simultaneously and partially.

\section{Internal Control Effect on Fraud Prevention}

The relation between internal control and fraud prevention exposed by (Sukrisno, 2012:212) is if internal control of an institution is weak, there will be a big chance of fraud and errors. On the contrary, if the internal control in an institution is strong, the chance of fraud and errors will be relatively small. The paradigms in this research are as follows:

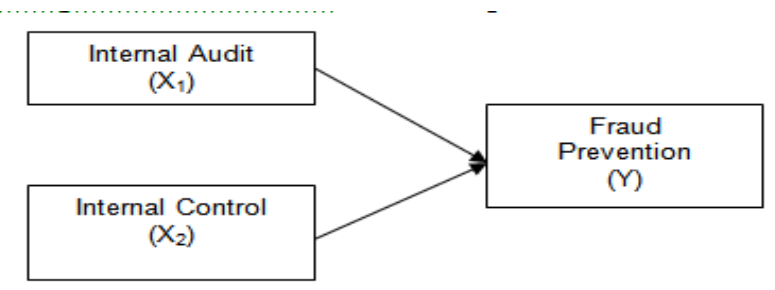

FIGURE 1. Research model

\section{Hypothesis}

H1: Internal audit affects the fraud prevention

H2: Internal Control affects fraud prevention

\section{METHODOLOGY}

The methods used for this research are descriptive and verificative. By these methods, the relation among observed variables can be obtained to produce conclusions.

Descriptive method is a way to make description or view systematically, factually, and accurately on facts and nature of observed phenomena. Verificative method is to test the theory and hypothesis offered by experts on internal audit and internal control on fraud prevention. The verificative method used in this research is done by using statistical test i.e. structural equation model (SEM) based on variance or known as partial least square (PLS).

\section{Data Collection Techniques}

Data collecting techniques used in this research are done in two ways, field research and literature review. Primary data collecting and secondary data collecting:

1. Field research

a. Interview

b. Questionnaires

c. Documentations

2. Literature review 
TABLE 1. Operational variables

\begin{tabular}{|c|c|c|c|c|}
\hline Variable & Variable Concept & Indicator & Scale & Questionnaire No. \\
\hline $\begin{array}{c}\text { Internal } \\
\text { Audit } \\
\left(\mathrm{X}_{1}\right)\end{array}$ & $\begin{array}{l}\text { Internal Audit is an } \\
\text { independent judgement } \\
\text { value in an organization to } \\
\text { test and evaluate } \\
\text { organization activities } \\
\text { (Tugiman 2006:1) }\end{array}$ & $\begin{array}{l}\text { 1. Checking Planning } \\
\text { 2. Testing and } \\
\text { Evaluating } \\
\text { 3. Checking Result } \\
\text { Publicatoin } \\
\text { 4. Checking Follow Up } \\
\text { (Tugiman, 2006) }\end{array}$ & $\begin{array}{l}0 \\
\mathrm{R} \\
\mathrm{D} \\
\mathrm{I} \\
\mathrm{N} \\
\mathrm{A} \\
\mathrm{L}\end{array}$ & $\begin{array}{c}5-6 \\
7\end{array}$ \\
\hline $\begin{array}{c}\text { Internal } \\
\text { Control } \\
\left(\mathrm{X}_{2}\right)\end{array}$ & $\begin{array}{l}\text { Internal control is a process, } \\
\text { influenced by board of } \\
\text { commissioners, } \\
\text { management, and other } \\
\text { personnel entity designed to } \\
\text { provide trust in order to } \\
\text { achieve goals such as rigid } \\
\text { financial report, asset and } \\
\text { organization notes, } \\
\text { obedience of rules and } \\
\text { regulations, and effective } \\
\text { and efficient operations. } \\
\text { (Rahayu \& Suhayati } \\
\text { 2010:221) }\end{array}$ & $\begin{array}{l}\text { 1. Environment } \\
\text { Control } \\
\text { 2. Management Risk } \\
\text { Statement } \\
\text { 3. Control activities } \\
\text { 4. Accounting } \\
\text { Information and } \\
\text { Communication } \\
\\
\text { 5. Observation } \\
\text { (Rahayu \& Suhayati } \\
2010: 223 \text { ) }\end{array}$ & $\begin{array}{l}0 \\
\mathrm{R} \\
\mathrm{D} \\
\mathrm{I} \\
\mathrm{N} \\
\mathrm{A} \\
\mathrm{L}\end{array}$ & $\begin{array}{c}8-9 \\
10-11 \\
12-14 \\
15-16 \\
17\end{array}$ \\
\hline $\begin{array}{c}\text { Fraud } \\
\text { Prevention } \\
\text { (Y) }\end{array}$ & $\begin{array}{l}\text { Fraud prevention is activity } \\
\text { done by management to } \\
\text { implement policy, system } \\
\text { and procedures to ensure } \\
\text { that actions are done by } \\
\text { board of commissioners, } \\
\text { management, and other } \\
\text { personnel in a company to } \\
\text { provide trust to achieve } \\
\text { three main points, rigid } \\
\text { financial report, effective } \\
\text { and efficient operations and } \\
\text { obedience of rules and } \\
\text { regulations. } \\
\text { (Amrizal 2004:5) }\end{array}$ & $\begin{array}{l}\text { 1. Good Internal } \\
\text { Control System } \\
\text { Structure } \\
\text { 2. To make effective } \\
\text { use of control } \\
\text { activity } \\
\text { 3. Organization } \\
\text { culture } \\
\text { improvement } \\
\text { 4. To make effective } \\
\text { use of internal } \\
\text { audit } \\
\text { function(Amrizal } \\
\text { 2004:5) }\end{array}$ & $\begin{array}{l}\mathrm{O} \\
\mathrm{R} \\
\mathrm{D} \\
\mathrm{I} \\
\mathrm{N} \\
\mathrm{A} \\
\mathrm{L}\end{array}$ & $\begin{array}{l}20 \\
21\end{array}$ \\
\hline
\end{tabular}




\section{Analysis Unit}

Analysis unit in this research is auditor and P2UPD in inspectorate which audits regional government work union (SKPD) Bandung district of 33 SKPD.

\section{RESEARCH RESULTS}

\section{Descriptive Analysis Results}

Internal audit descriptive analysis: In overall response from respondents, it is known that the score of internal audit variable is $85.90 \%$. This value if referred to criteria by Narimawati (2008:85) is categorized as very good within the interval of $84.01 \%-100 \%$, so it is concluded that the value is scored as very good.

\section{Internal Control Descriptive Analysis}

In overall response from respondents, it is known that the percentage value obtained for internal control variable is $74.06 \%$. This value if referred to criteria by Narimawati (2008:85) is categorized as good within $68.01 \%-84 \%$ interval, so it is concluded that internal control overall is scored as good.

\section{Fraud Prevention Descriptive Analysis}

In overall response from respondents, it is known that the percentage value for fraud is $71.67 \%$. This value if referred to criteria by Narimawati (2008:85) is categorized as good within $68.01 \%-84 \%$ interval, so it is concluded that the overall score is good.

\section{Verificative Analysis}

\section{Internal Audit on Fraud Detection Verificative Analysis} Result

Based on data analysis using Smart PLS 2.0 software, the verificative internal audit result can be explained as below: 1. Correlated coefficient value for internal audit (X1) with fraud prevention $(\mathrm{Y})$ is about 0.422 and categorized as intermediate/sufficient within $0.40-0.70$ interval. This means internal audit has a positive effect on fraud prevention. Where if internal audit runs well, fraud prevention will also be better. On the contrary, if internal audit performance is reduced then fraud prevention will also be reduced.

2. Determination coefficient (partial) of internal audit (X1) gives an effect for $8.566 \%$ on fraud prevention $(\mathrm{Y})$ and categorized as very low $>0.40$. While the remaining $91.434 \%$ is a factor unobserved in this research. 3. Determination coefficient value (overall) of internal audit (X1) and internal control (X2) altogether give contribution for $36.44 \%$ (intermediate/sufficient) on fraud prevention (Y). While the remaining $64.56 \%$ is other factor unobserved in this research.

\section{Verificative Analysis Result of Internal Control on Fraud Prevention}

Based on data analysis using Smart PLS 2.0, the verificative analysis result of internal audit on fraud prevention can be explained as below:

1. Correlation Coefficient value obtained between internal control (X2) with fraud prevention (Y) is 0.576 and categorized as intermediate/sufficient within 0.40 0.70 interval. This means the internal control has a positive effect on fraud prevention. If the internal control is better, then fraud prevention will also be better. On the contrary, if internal control is reduced so fraud prevention will also be reduced.

2. Determination coefficient (partial) of internal control (X2) provides a good effect of $27.878 \%$ on fraud prevention $(\mathrm{Y})$ and categorized as intermediate/sufficient within $0.16-0.49$ interval. While the remaining $72.122 \%$ is factor unobserved in this research.

3. The determination coefficient (overall) of internal audit (X1) and internal control (X2) altogether provide contribution factor of $36.44 \%$ and categorized as intermediate/sufficient on fraud prevention (Y), while the remaining $63.56 \%$ is factor unobserved in this research.

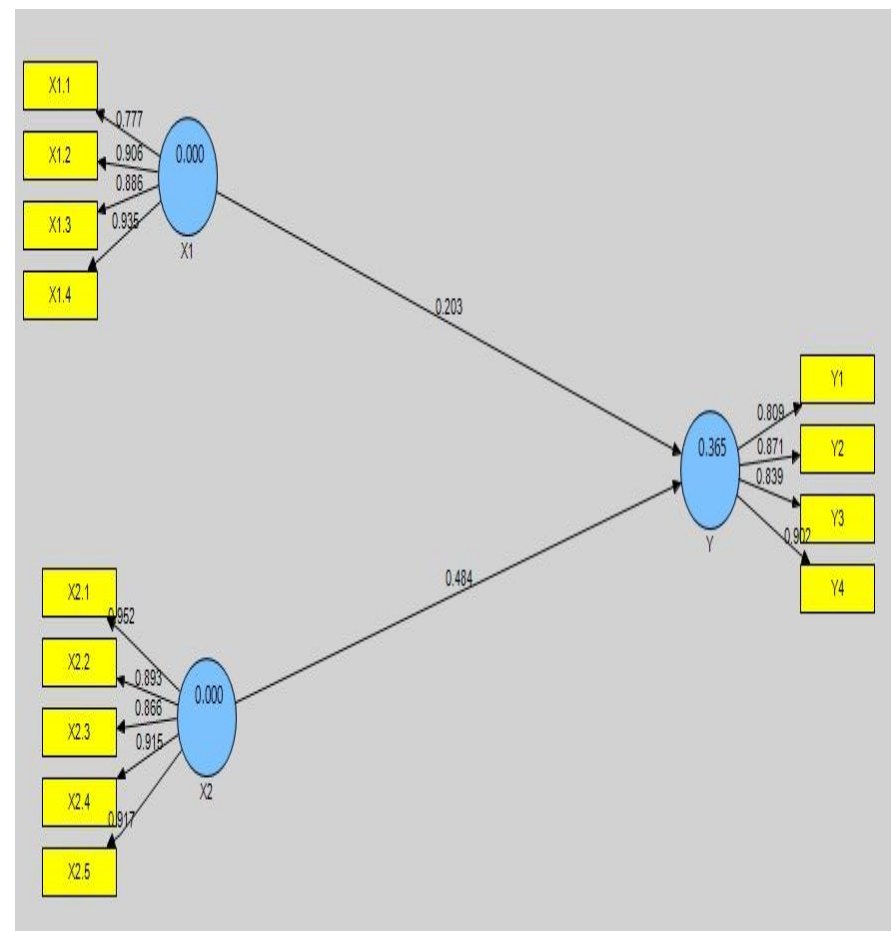

FIGURE 2. Relationship between internal audit and fraud prevention 


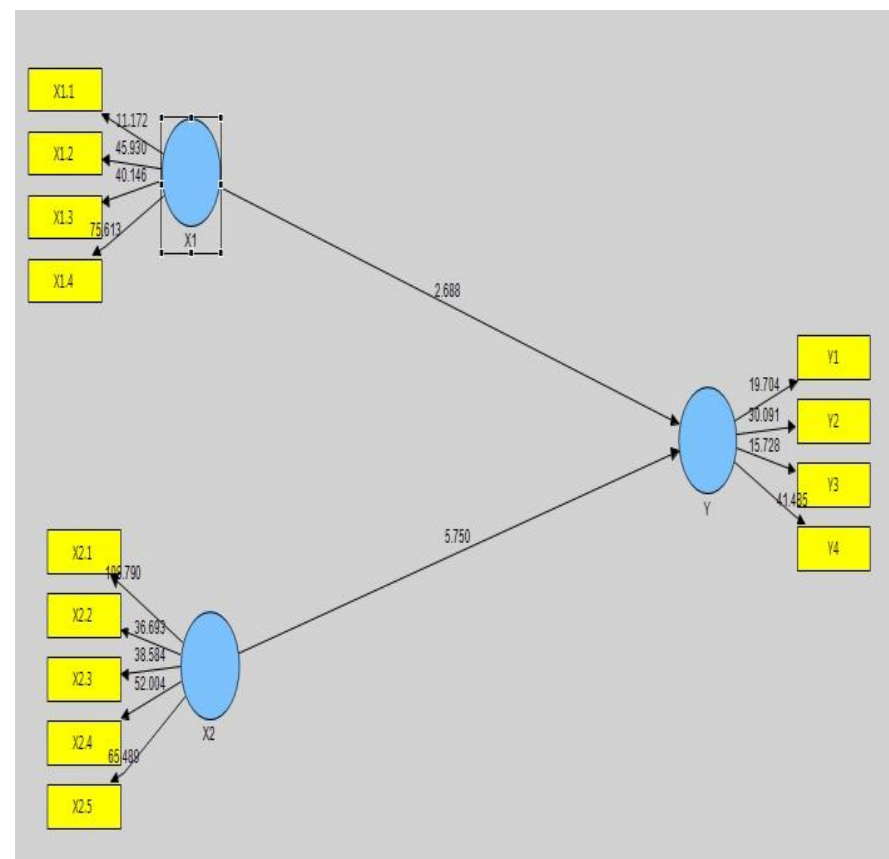

FIGURE 3. Relationship between internal control and fraud prevention

R Square

\begin{tabular}{|c|c|}
\hline & R Square \\
\hline $\mathbf{X 1}$ & \\
\hline $\mathbf{X 2}$ & \\
\hline $\mathbf{Y}$ & 0.364665 \\
\hline
\end{tabular}

Table of contents

Cross Loadings

\begin{tabular}{|c|c|c|c|}
\hline & $\mathbf{X 1}$ & $\mathbf{X 2}$ & $\mathbf{Y}$ \\
\hline $\mathbf{X 1 . 1}$ & 0.776778 & 0.355581 & 0.289752 \\
\hline $\mathbf{X 1 . 2}$ & 0.906298 & 0.509199 & 0.344743 \\
\hline $\mathbf{X 1 . 3}$ & 0.886204 & 0.346405 & 0.371522 \\
\hline $\mathbf{X 1 . 4}$ & 0.935001 & 0.395121 & 0.451736 \\
\hline $\mathbf{X 2 . 1}$ & 0.452444 & 0.951549 & 0.475255 \\
\hline $\mathbf{X 2 . 2}$ & 0.465830 & 0.893471 & 0.428249 \\
\hline $\mathbf{X 2 . 3}$ & 0.391457 & 0.865718 & 0.616875 \\
\hline $\mathbf{X 2 . 4}$ & 0.398986 & 0.914501 & 0.581690 \\
\hline $\mathbf{X 2 . 5}$ & 0.363113 & 0.916648 & 0.456337 \\
\hline $\mathbf{Y 1}$ & 0.410862 & 0.399666 & 0.808535 \\
\hline $\mathbf{Y 2}$ & 0.336180 & 0.586013 & 0.870746 \\
\hline $\mathbf{Y 3}$ & 0.339680 & 0.456858 & 0.838599 \\
\hline Y4 & 0.369955 & 0.508362 & 0.901949 \\
\hline
\end{tabular}

\section{Redundancy}

\begin{tabular}{|c|c|}
\hline & redundancy \\
\hline $\mathbf{X} 1$ & \\
\hline $\mathbf{X} 2$ & \\
\hline $\mathbf{Y}$ & 0.095942 \\
\hline
\end{tabular}

Table of contents

\section{Cronbachs Alpha}

\begin{tabular}{|c|c|}
\hline & Cronbachs Alpha \\
\hline $\mathbf{X 1}$ & 0.899964 \\
\hline $\mathbf{X 2}$ & 0.947524 \\
\hline $\mathbf{Y}$ & 0.877819 \\
\hline
\end{tabular}

Table of contents

Latent Variable Correlations

\begin{tabular}{|c|c|c|c|}
\hline & $\mathbf{X 1}$ & $\mathbf{X 2}$ & $\mathbf{Y}$ \\
\hline $\mathbf{X 1}$ & 1.000000 & & \\
\hline $\mathbf{X 2}$ & 0.454384 & 1.000000 & \\
\hline $\mathbf{Y}$ & 0.422686 & 0.576247 & 1.000000 \\
\hline
\end{tabular}

FIGURE 4. Correlation and regression results

\section{Analysis}

\section{Analysis Result on Fraud Prevention}

Based on field research, internal audit effect percentage is $8.566 \%$ on fraud prevention with a correlation value of 0.422 which means internal audit provides an intermediate/sufficient value towards a positive effect on fraud prevention in District of Bandung Government. The positive internal control value with fraud prevention shows that a better internal audit will be followed by better fraud prevention as well. This research reveals that internal audit provides $8.566 \%$ effect on fraud prevention, while the remaining $91.434 \%$ is influenced by other unobserved factors. From the descriptive analysis result, it is revealed that internal audit has a respondent percentage of $85.90 \%$ and categorized as very good which means that internal audit is very good. This is proven by good respondent indicator with a value of $87.87 \%$, next the indicator of checking planning with a value of $86.975 \%$, the indicator of checking follow up with a value of $85.45 \%$ and the lowest value is testing and evaluating with a value 
of $71.67 \%$ and categorized as good which means fraud prevention is good. This is proven by the highest indicator from respondents which are internal control structure with a value of $76.97 \%$. Indicator to make effective use of internal audit function is $71.52 \%$, next an indicator to make effective use of control activity has value of $70.30 \%$, and the lowest indicator to improve organizational culture with a value of $67.8 \%$ but at this present tame there is a gap with a value of $28.33 \%$. So in order to improve internal audit, we can look at loading factor, done by increasing checking planning (0.777), testing and evaluating (0.906), checking result publication (0.886), and checking follow up (0.935). Besides we can do fraud prevention by building good internal control (0.809), to make effective use of control activity (0.871), improving organizational culture (0.839), and to make effective use of internal audit functions (0.902).

The research result proves empirically that internal audit affects fraud prevention, where good internal audit will improve fraud prevention in District of Bandung Government. The research result is supported by theory stating that inappropriate internal audit will increase the opportunity of administrative fraud (Amin Widjaja Tunggal (2012:134). The research has also supported that better internal audit will cause higher prevention effort (Festi \& Natariasari, 2014).

\section{Internal Control Influence on Fraud Prevention}

Based on field research, internal control has a big effect with a value of $27.878 \%$ on fraud prevention with a correlation value of 0.576 which means internal control system provides intermediate/sufficient value in a positive way on fraud prevention in District of Bandung Government. Internal control with fraud prevention

shows that good internal control will be followed by good fraud prevention. From this result it is known that internal control gives an effect with a value of $27.878 \%$ on fraud prevention, while the remaining $72.122 \%$ is affected by unobserved factors. From the descriptive analysis result it is proven that internal control has a respondent respond with a value of74.06 and categorized as good which means internal control is better. This is proven by the highest response with an indicator of risk management of 83.64\%, next the environment control factor of $75.45 \%$, accounting information and communication with a value of $67.27 \%$. There is a gap with a value of $32.73 \%$ which means the problems are within the internal control. Next one is fraud indicator to build good internal control with a value of $76.97 \%$, next to make effective use of internal audit control with a value of $71.52 \%$, next the indicator to make effective use of cultural organization with a value of $67.88 \%$ but there is still a gap with a value of $28.33 \%$. Prevention has the respondent with a value of $71.67 \%$ and categorized as good which means fraud prevention is good to counter existing problem in internal control can be seen on loading factor, can be done by improving environment control (0.952), risk management (0.893), control activity (0.866) by adding human resource in accounting so we could separate functions between recording, admitting, expense, and money keeping, accounting information system and communication (0.915), adding accounting information system or upgrading accounting information system and observation (0.917). Besides it can be done by improving internal control (0.809), to make effective use of control activity (0.871) increasing organization culture (0.839), and to make effective use of internal audit function (0.902). The research result proves empirically that internal control system affects fraud prevention, where good internal control will increase the fraud prevention in District of Bandung Government. The research result is supported by theory stating that if internal control within an institution is weak, there will be a bigger chance of fraud. On the contrary, if internal control is strong, there will be a bigger chance to prevent fraud (Sukrisno, 2012:212). The research result is also supported by previous researches stating that the better the internal control the stronger the effort to prevent fraud (Arfah, 2011).

\section{CONCLUSION AND RECOMMENDATIONS}

Based on data analysis and description of this research, we can conclude several things as follows:

1. Internal audit affects the fraud prevention in District of Bandung Government, means the better the internal audit the better the effort of fraud prevention.

2. Internal control affects fraud prevention in District of Bandung Government, means the better the internal control the better the fraud prevention. But in practice it is still not optimal because there are several problems:

a. Activity control on SKPD which is adequate on respondent is caused by inoptimal function splitting; record, admission, and expense

b. Accounting information and communication system in SKPD are still lacking, which causes accounting information system scored by respondents as still relevant. 


\section{REFERENCES}

Agung, R.I.G. 2010. Audit kinerja pada sector publik. Jakarta. ID: Grafindo.

Amalia, R. 2013. Pengaruh audit internal terhadap pencegahan dan pendeteksian fraud (kecurangan).

Amrizal, C.F.E. 2004. Pencegahan dan Pendeteksian Kecurangan oleh internal auditor. Jakarta, ID: Diklat bpkp.

Arfah, E.A. 2011. Pengaruh penerapan pengendalian internal terhadap pencegahan fraud pengadaan barang dan implikasinya pada kinerja keuangan. Jurnal Investasi, 7(2): 137-153.

Aziz, H.A. 2014. Ikhtisar hasil pemeriksaan keuangan republik indonesia semester i tahun 2014 bpk ri. Jakarta, ID: Pusat

Didi, W. 2008. BPKP diminta bekerja secara optimal. Merdeka.com

Festi, T., \& Natariasari, R. (2014). Pengaruh peran audit internal terhadap pencegahan kecurangan (studi empiris pada perbankan di pekanbaru). Jurnal Online Mahasiswa (JOM) Bidang IImu Ekonomi, 1(2): 1-16.

Gusnardi. 2011. pengaruh komite audit, pengendalian internal, audit internal, dan pelaksanaan tata kelola perusahaan terhadap pencegahan kecurangan. Ekuitas, 15(1): 130-146.

Hery. 2010. Potret profesi audit internal. Bandung, ID: Alfabeta.

Mulyani, P., \& Suryawati, R.F. 2013. Analisis peran dan fungsi sistem pengendalian intern pemerintah (SPIP/PP No. 60 Tahun 2008) dalam meminimalisasi tingkat Salah Saji Pencatatan Akuntansi Keuangan Pemerintah Daerah. Jurnal Organisasi Dan Manajemen, 7(2): 102-116.

Narimawati, U. 2008. Metodologi penelitian kualitatif dan kuantitatif, teori dan aplikasi. Bandung, ID: Agung Media.

Nisak, C., \& Kurniawan, F.A. 2013. Sistem pengendalian intern dalam pencegahan fraud pada satuan kerja perangkat daerah (SKPD) pada kabupaten bangkalan. Journal of Auditing, Finance \& Forensic Accounting 1(1): 15-22.

Rahayu, S.K., \& Suhayati, E. 2010. Auditing: Konsep dasar dan pedoman pemeriksaan akuntan public. Yogyakarta, ID: Graha Ilmu.

Robert, E.J. 2013. Korupsi dan otonomi daerah bagai sejoli kepala daerah korup. Merdeka.Com

Sukrisno, A. 2012. Auditing. Jakarta, ID: Salemba Empat.

Tuanakotta, T.M. 2010. Akuntansi forensik dan audit investigatif . Jakarta, ID: Salemba Empat.

Tugiman, H. 2006. Standar profesional audit internal. Yogyakarta, ID: Kanisius.

Widilestariningtyas. O. 2012. Pengaruh audit internal, pengendalian internal, dan good government governance terhadap pencegahan fraud dan implikasinya terhadap kinerja pemerintah daerah. Indonesian Journal of Economics \& Busines, 2(2): 1-14.

Widjaja, A. 1992. Pemeriksaan kecurangan (fraud auditing). Jakarta, ID: Rineka Cipta.

— This article does not have any appendix. - 